\title{
Diversifying the technological strategies for recovering bioenergy from the two-phase anaerobic digestion of sugarcane vinasse: An integrated techno-economic and environmental approach
}

\author{
Lucas Tadeu Fuess ${ }^{a,}{ }^{*}$, Bruno Colling Klein ${ }^{b}$, Mateus Ferreira Chagas ${ }^{b}$, \\ Mylene Cristina Alves Ferreira Rezende ${ }^{\mathrm{b}}$, Marcelo Loureiro Garcia ${ }^{\mathrm{c}}$, Antonio Bonomi ${ }^{\mathrm{b}}$, \\ Marcelo Zaiat ${ }^{\text {a }}$ \\ a Biological Processes Laboratory (LPB), São Carlos School of Engineering (EESC), University of São Paulo (USP), Av. João Dagnone, 1100, Santa Angelina, São \\ Carlos, São Paulo 13563-120, Brazil \\ ${ }^{\mathrm{b}}$ Laboratório Nacional de Ciência e Tecnologia do Bioetanol (CTBE), Centro Nacional de Pesquisa em Energia e Materiais (CNPEM), Rua Giuseppe Máximo \\ Scolfaro, 10000, Polo II de Alta Tecnologia, P.O. Box 6170, Campinas, São Paulo 13083-970, Brazil \\ c São Paulo State University (UNESP), Institute of Geosciences and Exact Sciences (IGCE), Campus of Rio Claro. Av. 24-A, 1515, Bela Vista, Rio Claro, São Paulo \\ 13506-900, Brazil
}

Keywords:

Two-phase biodigestion

Sugarcane vinasse

Techno-economic assessment

Life cycle assessment

Bioenergy recovery

\begin{abstract}
A B S T R A C T
Technical, economic and environmental aspects of implementing two-phase anaerobic digestion (AD), i.e., acidogenic + methanogenic systems, in sugarcane biorefineries for the treatment of vinasse were assessed based on different strategies to using the hydrogen-rich biogas (biogas- $\mathrm{H}_{2}$ ) generated via acidogenesis. Phase separation greatly enhanced the bioenergy recovered from vinasse AD compared with single-phase systems (methanogenic phase exclusively). The best results for generating electric energy were observed in combined cycle-based power plants that utilized biohythane (10.8 MW + 5.5 MW for the harvest and inter-harvest, respectively), which is the gaseous biofuel from blending biogas $-\mathrm{H}_{2}$ with the methane-rich stream from the methanogenic phase (biogas- $\mathrm{CH}_{4}$ ). Moreover, the results of this study indicated that scaling up two-phase AD systems is economically feasible for the treatment of sugarcane vinasse (net present value $=$ USD 208.58-219.86 million) because a better or equivalent economic performance was attained compared with single-phase processes. Optimizing the alkalinization of methanogenic reactors strongly affected both the economic and environmental performance of the process, with better results observed with the use of low sodium hydroxide dosages ( $4 \mathrm{~g}$ $\mathrm{NaOH} \mathrm{kg}{ }^{-1} \mathrm{COD}$ ). In summary, our results highlighted that two-phase biodigestion may enhance energy production from vinasse by $20-30 \%$ without impairing the profitability of the biorefinery and could lead to slight improvements in the environmental performance of the ethanol production chain via the use of an optimized alkalinization strategy.
\end{abstract}

๑) 2018 Elsevier Ltd. All rights reserved.

\footnotetext{
Abbreviations: AD, anaerobic digestion; ALO, agricultural land occupation; BFR, biogas flow rate; CB-0, reference scenario; CC, combined cycle; CE-1-CE-5, energy

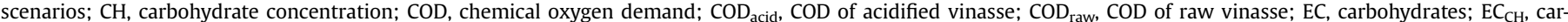

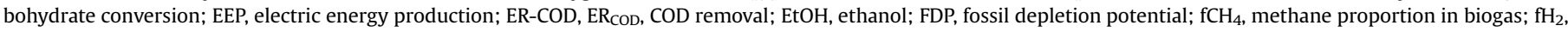

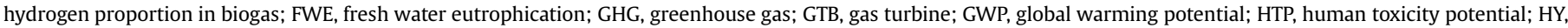

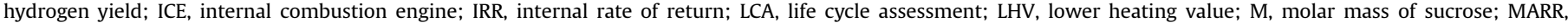

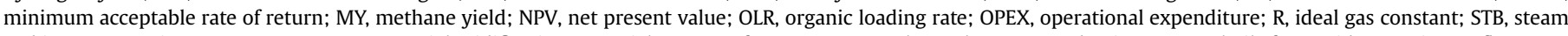

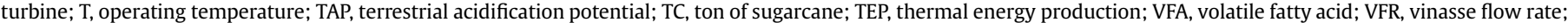
VSB, Virtual Sugarcane Biorefinery.

* Corresponding author.

E-mail addresses: ltfuess@alumni.usp.br (L.T. Fuess), bruno.klein@bioetanol.org.br (B.C. Klein), mateus.chagas@bioetanol.org.br (M.F. Chagas), mylene.rezende@bioetanol org.br (M.C. Alves Ferreira Rezende), mlgarcia@rc.unesp.br (M.L. Garcia), antonio.bonomi@bioetanol.org.br (A. Bonomi), zaiat@sc.usp.br (M. Zaiat).
} 


\section{Introduction}

The concept of biorefining has recently attracted great interest in the agro-industrial sector because of the potential to expand the exploitation of raw materials by simultaneously producing different types of value-added products and/or recovering energy directly from residues [1]. Sugarcane-based sugar and ethanol plants are important examples of biorefineries based on the conversion of feedstock into sugar, ethanol, and even electricity because burning bagasse and straw in boilers may result in surplus electric energy sold to the grid [2]. Despite the efficient utilization of sugarcane in such facilities, a considerable fraction of the sugarcane energy content remains in the vinasse as residual organic matter from fermentation. Most of the organic content of vinasse is composed of easily degradable compounds, such as unconverted organic matter (residual fractions of reducing sugars and sucrose), compounds formed in competing fermentative metabolic pathways (glycerol and organic acids), and unrecovered fractions of ethanol [3].

In Brazil, sugarcane vinasse is commonly returned to the sugarcane fields via fertirrigation to recycle water and nutrients, predominantly potassium [4], to the crop. Although studies have associated beneficial results with fertirrigation [5,6], including reduced expenses from inorganic fertilizers, disposing vinasse on land may generate several negative impacts for the soil-water-plant system over the long term [4,7]. The biorefinery concept indicates that the direct land application of vinasse reflects the underuse of a highly energetic raw material because biotechnological approaches are potentially suitable for the processing of such wastewater particularly via anaerobic processes.

Reference studies highlight the suitability of anaerobic digestion (AD) or biodigestion as the core technology for the treatment of vinasse, and they primarily focus on the reduction of organic polluting loads with bioenergy recovery through biogas production in single-phase anaerobic digesters [8-12]. Recently, research groups have also investigated the suitability of biohydrogen production from such wastewater [13-15] and proposed the operation of an acidogenic phase prior to methanogenesis. The high levels of residual sugars from vinasse may be directly fermented into hydrogen $\left(\mathrm{H}_{2}\right)$ and volatile fatty acids (VFAs) by acidogenic bacteria, which greatly increases the resource recovery efficiency in sugarcane biorefineries. In short, phase separation may be directed to the enhanced production of value-added biochemicals, which is primarily based on the recovery of VFAs, whereas bioenergy generation is maximized when the acidified effluent is applied to subsequent methanogenic reactors [1,16]. Particularly, phase separation provides a range of important benefits over methanogenic systems based on the marked improvements in the biodegradability of the wastewaters [17]. Higher process stability also leads to lower inputs of alkalizing compounds into digesters, which may directly affect the economic impact of the process [18].

Considering the suitability of two-phase AD for the treatment of vinasse, investigations are required to achieve a better understanding of the energetic potential of the $\mathrm{H}_{2}$ - and methane $\left(\mathrm{CH}_{4}\right)-$ rich biogas streams, i.e., biogas- $\mathrm{H}_{2}$ and biogas $-\mathrm{CH}_{4}$, respectively, resulting from vinasse biodigestion by providing the conditions for simulating scenarios in large-scale plants. The production of electricity is one of the potential uses of biogas that can maximize energy recovery [19] based mainly on the availability of consolidated efficient conversion technologies, such as engines and turbines [20]. Particularly in AD systems with phase separation, the biogas $-\mathrm{H}_{2}$ resulting from the acidogenic step could play a key role in improving the generation of energy based on different technological approaches. Biogas $-\mathrm{H}_{2}$ may be blended with the biogas collected from the methanogenic phase (biogas- $\mathrm{CH}_{4}$ ) to form biohythane, which can improve the methane fuel properties, such as flame speed, range of flammability, and quenching distance [21]. A few recent studies have addressed the production of biohythane for bioenergy recovery from $\mathrm{AD}[22,23]$. However, the energetic potential of biohythane is not addressed in detail in such cases. Another option includes the injection of biogas- $\mathrm{H}_{2}$ into the methanogenic reactor, which represents an in situ biogas- $\mathrm{CH}_{4}$ upgrade by increasing the $\mathrm{CH}_{4}$ content via the conversion of $\mathrm{H}_{2}$ and carbon dioxide $\left(\mathrm{CO}_{2}\right)$ by hydrogenotrophic methanogenesis [24,25].

In this context, this paper aims to assess different technological routes for bioenergy recovery from vinasse two-phase AD in firstgeneration sugarcane biorefineries based on the use of biogas- $\mathrm{H}_{2}$ for different purposes: blending with biogas- $\mathrm{CH}_{4}$ for biohythane production, injecting into methanogenic digesters for upgraded biogas- $\mathrm{CH}_{4}$ production, and selling as a value-added product. Scenarios with two-phase AD without biogas- $\mathrm{H}_{2}$ recovery and singlephase $A D$ were also considered to assess the energy generation capacity of different prime movers, i.e., internal combustion engines (ICEs), gas turbines (GTBs) and GTBs followed by steam turbines (STBs). The influence of different alkalizing strategies in the methanogenic phase over the economic and environmental performance of the biorefinery was also assessed based on different approaches, such as the use of sodium bicarbonate $\left(\mathrm{NaHCO}_{3}\right)$ and sodium hydroxide $(\mathrm{NaOH})$. The integration of vinasse biodigestion was compared with the usual scheme of sugarcane biorefineries in Brazil, in which vinasse is directed to fertirrigation without any processing. Experimental data from the literature $[15,17,26]$ were used to simulate the performance of single- and two-phase AD systems, and the Virtual Sugarcane Biorefinery (VSB) methodological framework was used to compare the scenarios in terms of their techno-economic and environmental performance. The VSB is a tool developed by the Brazilian Bioethanol Science and Technology Laboratory (CTBE) used to assess the technical, economic, environmental and social impacts by integrating the entire sugarcane production chain [27]. In particular, this is the first study presenting a holistic technological assessment for recovering and using $\mathrm{H}_{2}$ in full-scale sugarcane vinasse-fed biodigestion systems, in order to investigate the competitiveness of applying phase separation compared to conventional single-phase AD layouts.

\section{Methods}

\subsection{Scenario description and inputs for the technological assessment}

The reference scenario (CB-0) considered an annexed optimized biorefinery producing sugar, first-generation ethanol and electricity from conventional sugarcane during the harvesting season. This scenario also considered the use of energy cane during the inter-harvesting period of the conventional sugarcane. The recovery of lignocellulosic material from sugarcane fields (trash) was set to $50 \%$ and $100 \%$ (the leaves and tops of energy cane are harvested together with the stalks) for the harvesting and inter-harvesting periods, respectively [28]. Table 1 presents the input parameters and production data for the optimized biorefinery, which constitutes an improved standard plant characterized by a more efficient use of steam and, consequently, lower energy consumption levels [29]. Sugar (50\% of the juice), ethanol (50\% of the juice + molasses) and electric energy ( $100 \%$ of the bagasse $+50 \%$ of the straw) are the products obtained during the harvest season. Because the higher content of reducing sugars in energy cane hinders the crystallization of sucrose, only ethanol (100\% of the juice) and electric energy (from energy cane lignocellulosic material) are obtained during the inter-harvest period (Table 1 ).

Performance data from both single- and two-phase $\mathrm{AD}$ 
Table 1

Input data for the sugarcane biorefinery (sugar and ethanol production) and biodigestion plants.

\begin{tabular}{|c|c|c|}
\hline \multicolumn{3}{|l|}{ Optimized annexed biorefinery } \\
\hline Input data & Harvest & Inter-harvest \\
\hline Feedstock & Conventional cane & Energy cane \\
\hline Products & Ethanol, sugar and electricity & Ethanol and electricity \\
\hline Period (days) & 200 & 130 \\
\hline Milling capacity $\left(\mathrm{TC}^{\mathrm{a}}\right)$ & $4 \times 10^{6}$ & $1.7 \times 10^{6}$ \\
\hline Sugar production (ton) & $205.5 \times 10^{3}$ & - \\
\hline Ethanol production $\left(\mathrm{m}^{3}\right)$ & $214.5 \times 10^{3}$ & $95.2 \times 10^{3}$ \\
\hline Vinasse generation $\left(\mathrm{m}^{3}\right)$ & $1837.5 \times 10^{3}$ & $824.3 \times 10^{3}$ \\
\hline Specific vinasse generation ( $\mathrm{m}^{3}$ per $\mathrm{m}^{3}$ of ethanol) & 8.6 & 8.6 \\
\hline COD-vinasse $\left(\mathrm{g} \mathrm{L}^{-1}\right)$ & $28.3^{\mathrm{b}}$ & $21.0^{\mathrm{c}}$ \\
\hline Carbohydrates-vinasse $\left(\mathrm{g} \mathrm{L}^{-1}\right)$ & $5.6^{\mathrm{b}}$ & $5.6^{\mathrm{b}}$ \\
\hline \multicolumn{3}{|l|}{ Thermophilic AD system } \\
\hline \multirow[t]{4}{*}{ Single-phase $^{\mathrm{d}}$} & \multicolumn{2}{|l|}{$\mathrm{OLR}=25 \mathrm{~kg}-\mathrm{COD} \mathrm{m}{ }^{-3} \mathrm{day}^{-1}$} \\
\hline & \multicolumn{2}{|l|}{$\mathrm{ER}-\mathrm{COD}=60.7 \%$} \\
\hline & \multicolumn{2}{|c|}{$\mathrm{MY}=0.234 \mathrm{Nm}^{3}-\mathrm{CH}_{4} \mathrm{~kg}^{-1} \mathrm{COD}-$ removed } \\
\hline & \multicolumn{2}{|c|}{ Biogas- $\mathrm{CH}_{4}$ composition: $\mathrm{CH}_{4}(58.4 \%)+\mathrm{CO}_{2}(40.6 \%)+\mathrm{H}_{2} \mathrm{~S}(1.0 \%)$} \\
\hline \multirow{9}{*}{ Methanogenic step ${ }^{\mathrm{e}}$} & \multicolumn{2}{|c|}{$\mathrm{OLR}=84.2 \mathrm{~kg}-\mathrm{COD} \mathrm{m}^{-3} \mathrm{day}^{-1}$} \\
\hline & \multicolumn{2}{|l|}{$\mathrm{ER}-\mathrm{COD}=21.2 \%$} \\
\hline & \multicolumn{2}{|l|}{ EC-carbohydrates $=70.5 \%$} \\
\hline & \multicolumn{2}{|c|}{$\mathrm{HY}=3.4 \mathrm{~mol}-\mathrm{H}_{2} \mathrm{~mol}^{-1}$ carbohydrates-converted } \\
\hline & \multicolumn{2}{|c|}{ Biogas- $\mathrm{H}_{2}$ composition: $\mathrm{H}_{2}(37.0 \%)+\mathrm{CO}_{2}(63.0 \%)$} \\
\hline & \multicolumn{2}{|c|}{ OLR $=25 \mathrm{~kg}-\mathrm{COD} \mathrm{m}^{-3} \mathrm{day}^{-1}$} \\
\hline & \multicolumn{2}{|l|}{$\mathrm{ER}-\mathrm{COD}=73.9 \%$} \\
\hline & \multicolumn{2}{|c|}{$\mathrm{MY}=0.301 \mathrm{Nm}^{3}-\mathrm{CH}_{4} \mathrm{~kg}^{-1} \mathrm{COD}$-removed } \\
\hline & \multicolumn{2}{|c|}{ Biogas- $\mathrm{CH}_{4}$ composition: $\mathrm{CH}_{4}(70.0 \%)+\mathrm{CO}_{2}(29.0 \%)+\mathrm{H}_{2} \mathrm{~S}(1.0 \%)$} \\
\hline
\end{tabular}

Notes: ${ }^{\mathrm{a}} \mathrm{TC}=$ tonnes of cane; ${ }^{\mathrm{b}}$ Fuess et al. [15]; ${ }^{\mathrm{c}}$ Moraes et al. [10]; ${ }^{\mathrm{d}}$ Ferraz Jr. et al. [17]; ${ }^{\mathrm{e}}$ Fuess et al. [26].

Parameters (AD systems): OLR = organic loading rate; ER-COD $=$ COD removal; $M Y=$ methane yield; EC-carbohydrates $=$ carbohydrate conversion; HY $=$ hydrogen yield.

processes used to simulate biogas generation are also detailed in Table 1 based on experimental data for thermophilic temperature conditions $\left(55^{\circ} \mathrm{C}\right)[15,17,26]$. Although using experimental data to simulate full-scale processes may limit the extent of the analysis, the lack of pilot-to full-scale experiences with sugarcane vinasse in the Brazilian sucro-alcohol sector [26] dramatically reduces the availability of usable data in scenario prediction. Nevertheless, thermophilic systems constitute attractive alternatives for $\mathrm{AD}$ plants in distilleries and associate high treatment performance with the elimination of cooling systems prior to the digesters. Because vinasse is collected from distillation columns at temperatures above $85^{\circ} \mathrm{C}$, wastewater streams may reach the required temperature naturally in intermediate storage tanks and/or during the transportation to AD plants [10]. Five energy scenarios (CE-1 to CE-5) including $A D$ were compared based on the different layouts for the generation of electric and thermal energy from biogas $-\mathrm{H}_{2}$ and biogas- $\mathrm{CH}_{4}$ streams. Table 2 and Fig. 1 present an overview of each proposed energy scenario based on a comparison between single- and two-phase AD systems and an assessment of different applications for biogas- $\mathrm{H}_{2}$. Two-phase AD systems included approaches without biogas- $\mathrm{H}_{2}$ production (CE-1), biogas- $\mathrm{H}_{2}$ purification for sale (CE-2), biohythane production from biogas- $\mathrm{H}_{2}$ and biogas- $\mathrm{CH}_{4}$ blending (CE-3), and biogas- $\mathrm{CH}_{4}$ upgrading by injecting purified biogas- $\mathrm{H}_{2}$ into the methanogenic phase (CE-4). Singlephase AD was assessed in scenario CE-5. All scenarios considered the land application (fertirrigation) of the biodigested vinasse because $A D$ reduces the organic pollution load without impairing the fertilizing potential of the vinasse.

\subsection{Technical assessment: bioenergy generation from biogas}

Bioenergy generation from biogas in each scenario was assessed via the simulation of three prime movers available in commercial scale for biogas-based power plants: ICE, GTB, and a combined cycle (CC), i.e., GTB + STB. The technical specifications for each prime mover are presented in Table 3. The simulations were developed

Table 2

Overview of the assessed scenarios considering the implementation of biodigestion plants for the treatment of vinasse in first-generation sugarcane biorefineries.

\begin{tabular}{|c|c|c|c|c|c|c|c|c|}
\hline \multicolumn{3}{|l|}{ Scenario } & CB-0 & CE-1 & CE-2 & CE-3 & CE-4 & CE-5 \\
\hline \multicolumn{3}{|l|}{ AD plant } & No & Yes & Yes & Yes & Yes & Yes \\
\hline \multirow{2}{*}{\multicolumn{3}{|c|}{$\begin{array}{l}\text { Phase separation } \\
\text { Acidogenic phase }\end{array}$}} & - & Yes & Yes & Yes & Yes & No \\
\hline & \multicolumn{2}{|l|}{$\mathrm{pH}_{\text {control }}^{\mathrm{a}}$} & - & No & Yes & Yes & Yes & - \\
\hline & \multicolumn{2}{|c|}{ Biogas- $\mathrm{H}_{2}$ production } & - & No & Yes & Yes & Yes & - \\
\hline & \multirow[t]{2}{*}{ Biogas- $\mathrm{H}_{2}$} & $\mathrm{CO}_{2}$ removal $^{\mathrm{b}}$ & - & - & Yes & No & Yes & - \\
\hline & & Use & - & - & Purification for sale & Blending with biogas- $\mathrm{CH}_{4}^{\mathrm{c}}$ & $\begin{array}{l}\text { Purification for injection } \\
\text { into methanogenic reactor }\end{array}$ & - \\
\hline \multirow[t]{4}{*}{ Methanogenic phase } & \multicolumn{2}{|l|}{$\mathrm{pH}$ control $^{\mathrm{d}}$} & - & Yes & Yes & Yes & Yes & Yes \\
\hline & \multicolumn{2}{|c|}{ Biogas- $\mathrm{CH}_{4}$ production } & - & Yes & Yes & Yes & Yes & Yes \\
\hline & Biogas- $\mathrm{CH}_{4}$ & $\mathrm{CO}_{2}$ removal & - & No & No & No & No & No \\
\hline & & $\mathrm{H}_{2} \mathrm{~S}$ removal $^{\mathrm{e}}$ & - & Yes & Yes & Yes & Yes & Yes \\
\hline \multicolumn{3}{|c|}{ Biofuel for energy generation } & - & biogas- $\mathrm{CH}_{4}$ & biogas- $\mathrm{CH}_{4}$ & biohythane & biogas- $\mathrm{CH}_{4}$ & biogas- $\mathrm{CH}_{4}$ \\
\hline
\end{tabular}

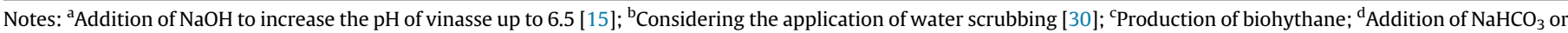

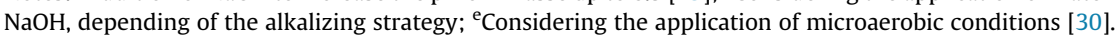




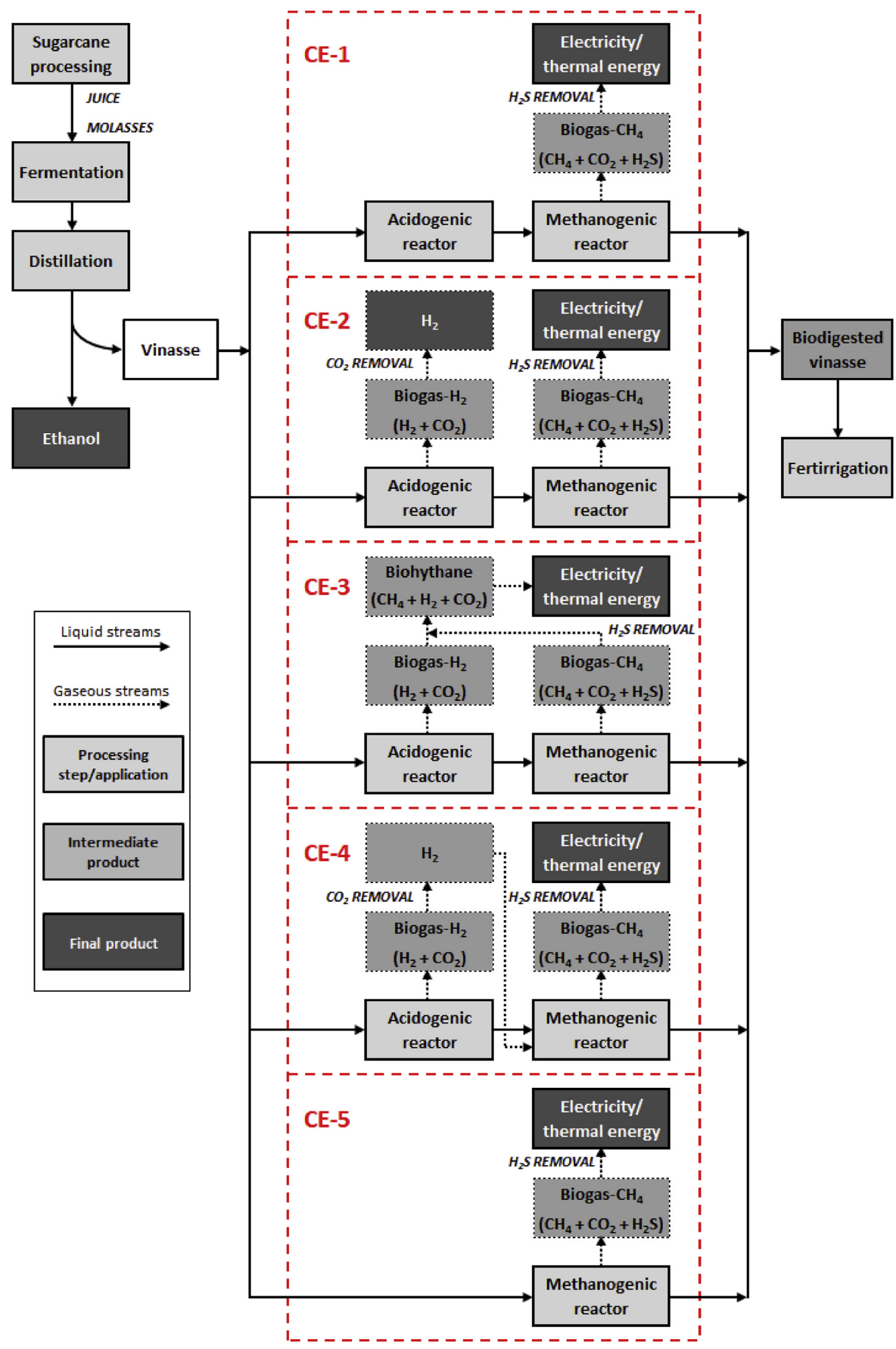

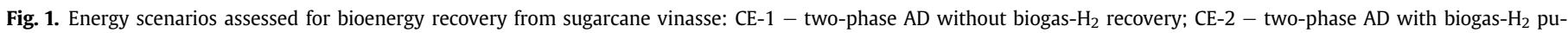

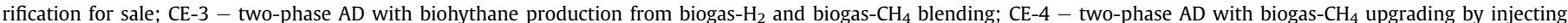
purified biogas- $\mathrm{H}_{2}$ into the methanogenic phase; and, CE-5 single-phase AD. 
with the aid of the software Aspen Plus ${ }^{\mathrm{TM}}$ (Aspen Technology, Inc., Bedford, MA, USA) using the VSB framework based on the technical specifications from each prime mover. Electric and thermal energy generation was considered in scenarios with ICE and GTB, whereas only electric energy generation was simulated for the cases with CC. The recovery of thermal energy was based on the production of hot water $\left(95^{\circ} \mathrm{C}\right)$ from the dissipated heat in intercoolers, lube oil and jacket water (ICE) and exhaust gas (ICE and GTB). Hydrogen sulfide $\left(\mathrm{H}_{2} \mathrm{~S}\right)$ removal from biogas- $\mathrm{CH}_{4}$ was considered in all cases using the maximum acceptable $\mathrm{H}_{2} \mathrm{~S}$ concentration for the ICE as a reference ( 1000 ppmv, Table 3).

\subsubsection{Basic calculations: biogas production and bioenergy recovery}

The calculation of biogas- $\mathrm{H}_{2}\left(\mathrm{Q}_{\text {biogas-H2 }} ; \mathrm{m}^{3} \mathrm{~h}^{-1}\right)$ and biogas- $\mathrm{CH}_{4}$ $\left(Q_{\text {biogas-CH4 }} ; \mathrm{m}^{3} \mathrm{~h}^{-1}\right.$ ) flow rates was implemented in Aspen Plus ${ }^{\mathrm{TM}}$ according to Equations (1) to (3), in which the terms VFR, $\mathrm{CH}, \mathrm{EC}_{\mathrm{CH}}$, $\mathrm{HY}, \mathrm{R}, \mathrm{T}, \mathrm{M}, \mathrm{fH}_{2}, \mathrm{COD}_{\text {acid }}, \mathrm{ER}_{\mathrm{COD}}, \mathrm{MY}, \mathrm{fCH}_{4}$ and $\mathrm{COD}_{\text {raw }}$ are the vinasse flow rate $\left(\mathrm{m}^{3} \mathrm{~h}^{-1}\right)$, the concentration of carbohydrates in raw vinasse $\left(\mathrm{g} \mathrm{L}^{-1}\right)$, the carbohydrate conversion efficiency in acidogenesis (dimensionless), the hydrogen yield $\left(\mathrm{mol} \mathrm{H}_{2} \mathrm{~mol}^{-1} \mathrm{CH}\right)$, the ideal gas constant $\left(0.082 \mathrm{~atm} \mathrm{~L} \mathrm{~mol}^{-1} \mathrm{~K}^{-1}\right)$, the operating temperature $\left(55^{\circ} \mathrm{C}\right)$, the molar mass of sucrose $\left(0.342 \mathrm{~kg} \mathrm{~mol}^{-1}\right)$, the proportion of $\mathrm{H}_{2}$ in biogas- $\mathrm{H}_{2}$ (dimensionless), the $\mathrm{COD}$ of the acidified vinasse $\left(\mathrm{g} \mathrm{L}^{-1}\right)$, the COD removal efficiency in methanogenesis (dimensionless), the methane yield $\left(\mathrm{L} \mathrm{CH}_{4} \mathrm{~g}^{-1} \mathrm{COD}, 55^{\circ} \mathrm{C}\right)$, the proportion of $\mathrm{CH}_{4}$ in biogas $-\mathrm{CH}_{4}$ (dimensionless) and the $\mathrm{COD}$ of the raw vinasse $\left(\mathrm{g} \mathrm{L}^{-1}\right)$, respectively. Equation (2) was used to obtain $\mathrm{Q}_{\text {biogas-CH4 }}$ in scenarios CE-1 to CE-4, whilst Equation (3) was used in scenario CE-5. $\mathrm{CH}, \mathrm{COD}_{\mathrm{raw}}, \mathrm{EC}_{\mathrm{CH}}, \mathrm{HY}, \mathrm{fH}_{2}, \mathrm{ER}_{\mathrm{COD}}, \mathrm{MY}$ and $\mathrm{fCH}_{4}$ values are summarized in Table 1, based on experimental data presented elsewhere $[15,17,26]$.

$\mathrm{Q}_{\text {biogas-H2 }}=\frac{\mathrm{VFR} \times \mathrm{CH} \times \mathrm{EC}_{\mathrm{CH}} \times \mathrm{HY} \times \mathrm{R} \times(273.15+\mathrm{T})}{1000 \times \mathrm{M} \times \mathrm{fH}_{2}}$

$\mathrm{Q}_{\text {biogas-CH4 }}=\frac{\mathrm{VFR} \times \mathrm{COD}_{\mathrm{acid}} \times \mathrm{ER}_{\mathrm{COD}} \times \mathrm{MY}}{\mathrm{fCH}_{4}}$

$\mathrm{Q}_{\text {biogas-CH4 }}=\frac{\mathrm{VFR} \times \mathrm{COD}_{\text {raw }} \times \mathrm{ER}_{\mathrm{COD}} \times \mathrm{MY}}{\mathrm{fCH}_{4}}$

Electric (EEP, MW) and thermal (TEP, MW) energy production values were obtained directly from the simulations of the ICE, GTB and CC, according to the technical specifications presented in Table 3 and biogas production resulting from the simulation of biodigestion systems (Equations 1-3). In turn, electric $\left(\eta_{\mathrm{el}}\right)$ and global $\left(\eta_{\text {global }}\right)$ energy conversion efficiencies were calculated according to Equations (4) and (5), in which the terms EEP, BFR, LHV and TEP are the electric energy production $(\mathrm{kW})$, the biogas flow rate $\left(\mathrm{m}^{3} \mathrm{~h}^{-1}\right)$, the lower heating value of biogas $\left(\mathrm{MJ} \mathrm{m} \mathrm{m}^{-3}\right)$ and the thermal energy production $(\mathrm{kW})$, respectively. BFR corresponds to the flow rate of biogas- $\mathrm{CH}_{4}$ in scenarios $\mathrm{CE}-1, \mathrm{CE}-2, \mathrm{CE}-4$ and $\mathrm{CE}-5$ and to the flow rate of biohythane, i.e., biogas- $\mathrm{H}_{2}+$ biogas $-\mathrm{CH}_{4}$, in CE-3. LHV values were also directly obtained in simulations according to the content of $\mathrm{CH}_{4}$ (biogas- $\mathrm{CH}_{4}$ ) and $\mathrm{H}_{2}+\mathrm{CH}_{4}$ (biohythane) in biogas streams.

$$
\begin{aligned}
& \eta_{\mathrm{el}}=\frac{\mathrm{EEP}}{\mathrm{BFR} \times \mathrm{LHV} \times 3.6} \\
& \eta_{\text {global }}=\frac{\mathrm{EEP}+\mathrm{TEP}}{\mathrm{BFR} \times \mathrm{LHV} \times 3.6}
\end{aligned}
$$

\subsection{Economic assessment methodology}

The economic impact of implementing AD treatment plants in distilleries was assessed by calculating the internal rate of return (IRR), net present value (NPV), and discounted payback period of the project with a minimum acceptable rate of return (MARR) of $12 \%$ per year. The project lifetime, depreciation, and construction periods were set as 25, 10 and 2 years, respectively, and the tax rates were fixed at $34 \%$. The investment and operating costs and selling prices were quoted in December 2015 using a conversion rate of USD 0.26 per unit of Brazilian real. The investment costs for the $\mathrm{AD}$ systems were estimated based on the design of treatment plants for both single- and two-phase processes as proposed by Fuess et al. [18], whereas reference data for the power plants (ICE, GTB, and CC) were obtained from the EPA [20]. Investments into $\mathrm{CO}_{2}$ and $\mathrm{H}_{2} \mathrm{~S}$ removal systems were obtained from Muñoz et al. [30] considering water scrubbing (CE-2 and $\mathrm{CE}-4$, biogas- $\mathrm{H}_{2}$ purification) and the application of microaerobic conditions (CE-1 to CE-5, biogas- $\mathrm{CH}_{4}$ purification), respectively.

With respect to the influence of the alkalizing strategy over the economics of the biorefinery, three alternatives were assessed based on the application of $\mathrm{NaHCO}_{3}$ or $\mathrm{NaOH}$ into the methanogenic phase: [i] application of $\mathrm{NaHCO}_{3}$ over the whole operating period of the plant $\left(\mathrm{NaHCO}_{3}\right.$-total), [ii] application of $\mathrm{NaHCO}_{3}$ only during the startup phase of the reactors (50 first days, $\mathrm{NaHCO}_{3}$ startup), and [iii] application of $\mathrm{NaOH}$ over the whole operating period ( $\mathrm{NaOH}$-total). For the alternatives "NaHCO 3 -total" and "NaHCO 3 -startup" dosages of $6.25 \mathrm{~g} \mathrm{NaHCO}_{3} \mathrm{~L}^{-1}$ vinasse [26] and $12.5 \mathrm{~g} \mathrm{NaHCO}_{3} \mathrm{~L}^{-1}$ vinasse [17] were considered for two- and singlephase systems, respectively, whereas for the alternative "NaOHtotal," these values corresponded to 89.2 and $113.2 \mathrm{mg} \mathrm{NaOH}$ $\mathrm{L}^{-1}$ vinasse, respectively, using the reference value of $4 \mathrm{~g} \mathrm{NaOH}$

Table 3

\begin{tabular}{|c|c|}
\hline Prime mover & Technical specifications \\
\hline ICE (J620 GS-F12,GE Jenbacher GmbH \& Co. OHG, Jenbach, Austria) & $\begin{array}{l}\text { Full load volumetric flow rate (air }+ \text { biogas })^{\mathrm{a}}=15,734 \mathrm{Nm}^{3} \mathrm{~h}^{-1} \\
\text { Compression ratio }(\varepsilon)=12.5 \\
\text { Thermal energy loss } \\
\text { Maximum } \mathrm{H}_{2} \mathrm{~S} \text { concentration }=2000 \mathrm{mg} \mathrm{Nm}^{-3} \mathrm{CH}_{4}\left(\sim 1000 \mathrm{ppm}_{\mathrm{v}}\right)\end{array}$ \\
\hline GTB $^{\mathrm{C}}$ (KG2-3E, Dresser-Rand, Kirkegaardsveien, Norway) & $\begin{array}{l}\text { Inlet pressure }=8 \text { bar } \\
\text { Exhaust gas temperature }=549{ }^{\circ} \mathrm{C} \\
\text { Maximum exhaust mass flow rate }=15 \mathrm{~kg} \mathrm{~s}^{-1}\end{array}$ \\
\hline STB (SST-110, Siemens AG - Energy Sector - Oil \& Gas Division, Duisburg, Germany) & $\begin{array}{l}\text { Inlet steam pressure }=131 \mathrm{bar} \\
\text { Inlet steam temperature }=530{ }^{\circ} \mathrm{C} \\
\text { Outlet steam pressure }=0.6 \mathrm{bar}\end{array}$ \\
\hline
\end{tabular}

Technical specifications of the prime movers assessed for bioenergy recovery.

\footnotetext{
a Biogas flow rate $=1090 \mathrm{Nm}^{3} \mathrm{~h}^{-1}$; biogas lower heating value $(\mathrm{LHV})=23.4 \mathrm{MJ} \mathrm{Nm}^{-3}$.

b Excluding thermal energy recovery through hot water.

${ }^{c}$ Model simulated in scenarios considering the GTB as the sole prime mover and its coupling with the STB (combined cycle).
} 
Energy production - harvest (MW)

0

5

10

15

200
Energy production - inter-harvest (MW)

9

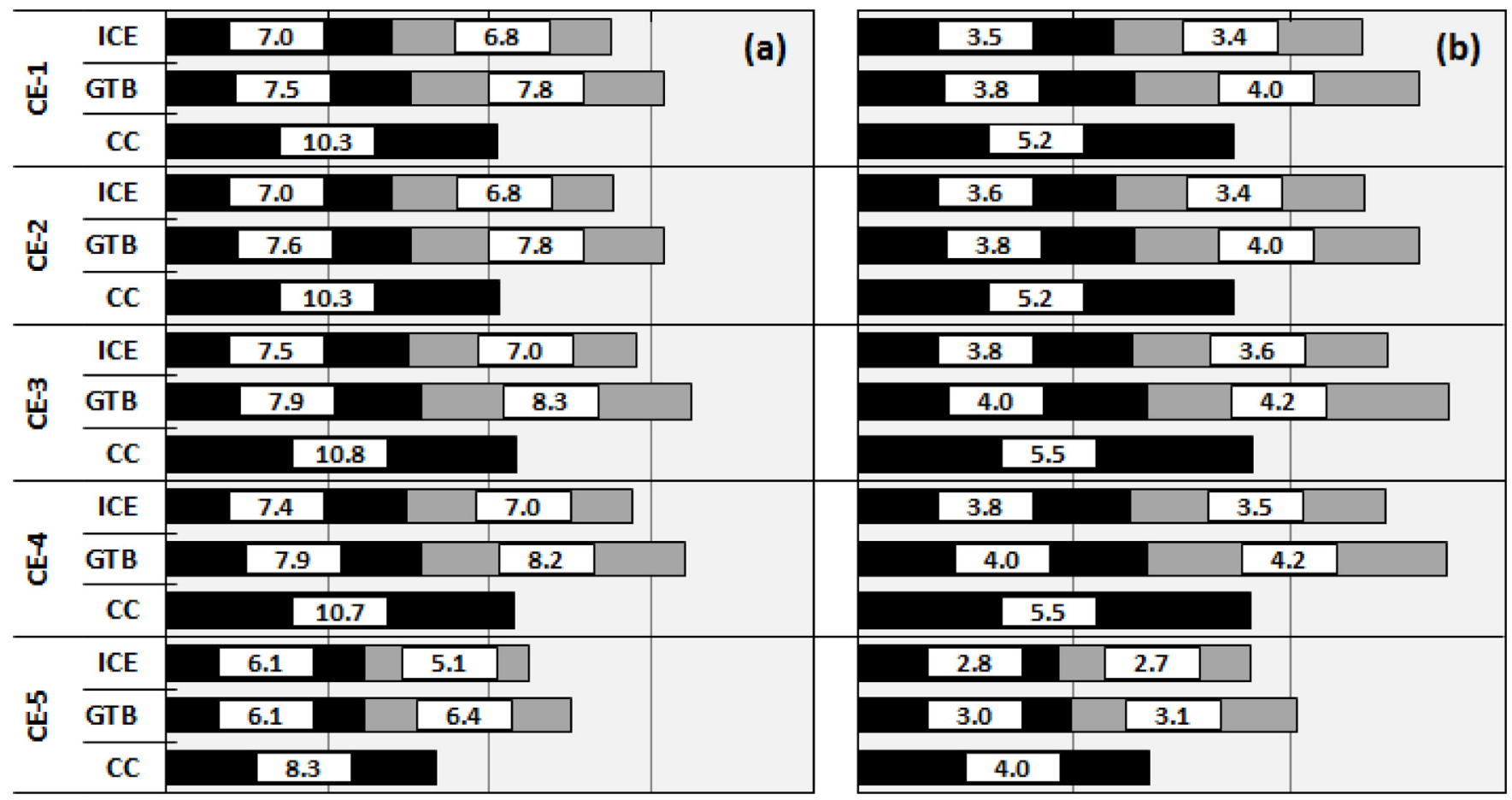

Energy conversion efficiency (\%)

0

25

50

75

100

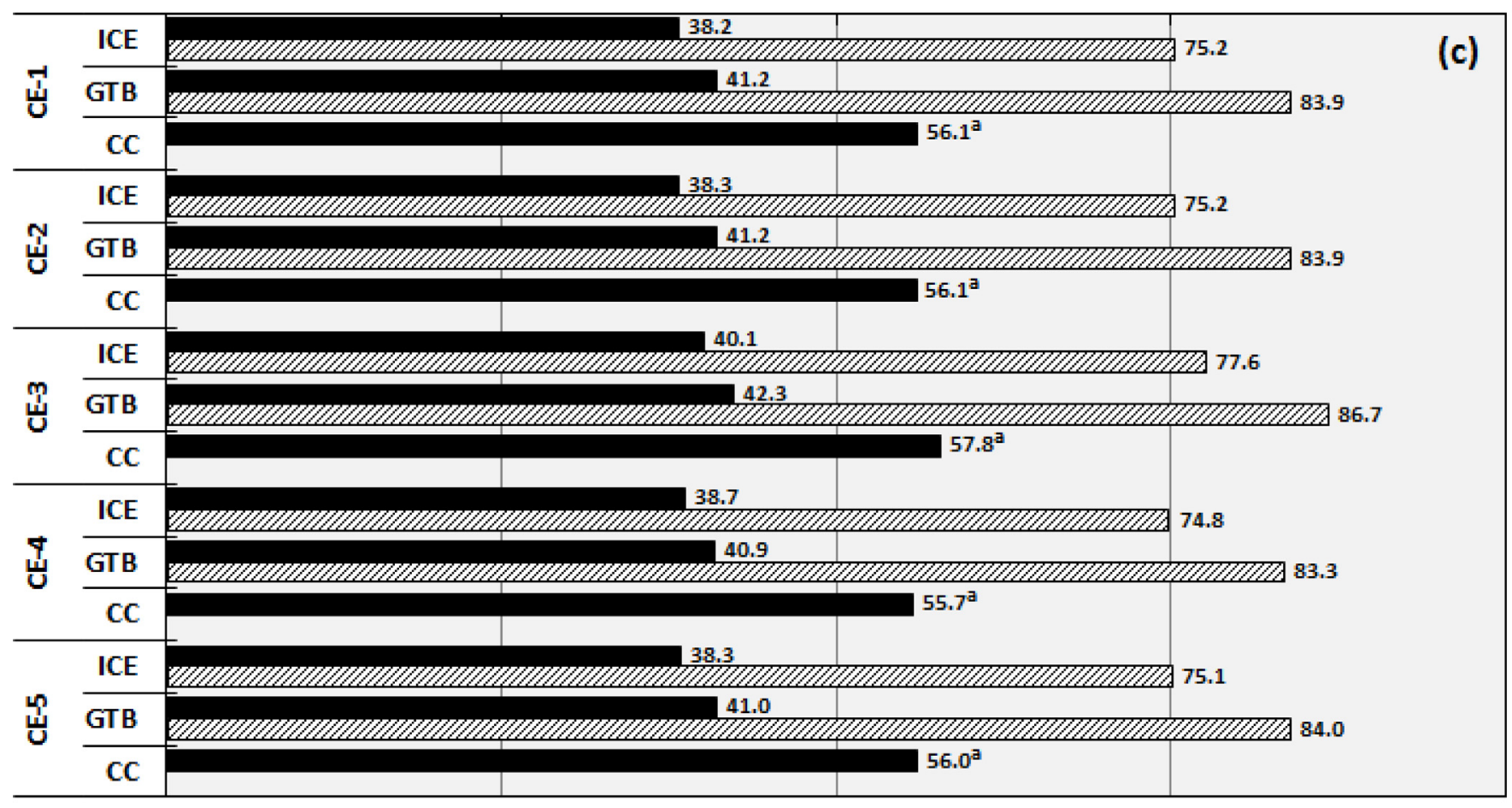

Electric energy production / $\square$ Thermal energy production electric conversion
Global conversion (electric+ thermal)

Fig. 2. Electric energy generation from biogas in the (a) harvesting and (b) inter-harvesting periods and (c) electric and total (electric + thermal) energy conversion for different prime movers. 
$\mathrm{kg}^{-1} \mathrm{COD}[8]$

\subsection{Environmental performance: life cycle assessment methodology}

The environmental performance of each scenario was assessed and compared according to the life cycle assessment (LCA) methodology described in the ISO 14040 series of standards [31,32]. Worldwide, the LCA is the most frequently used methodology for the environmental assessment of products and processes, including systems targeting bioenergy production $[2,29,33]$. These assessments consider the impacts from resource use and emissions that are typically observed in the most common bioenergy systems. Substantially broader environmental aspects can be covered, ranging from greenhouse gas (GHG) emissions and fossil resource depletion to acidification, toxicity, and land use aspects.

SimaPro software [34] was used as a tool for this environmental assessment, and the ecoinvent database v2.2 [35] was used to obtain the environmental profile of the main inputs for the biorefinery, which considered both agricultural and industrial processes (e.g., diesel, fertilizers, pesticides and other chemicals used as inputs in the processes, such as the alkalizing compounds required for biodigestion). The use of resources and emissions to the soil, air, and water throughout the entire production chain were converted into different environmental impact categories using environmental impact assessment methods that are internationally recognized and published in the scientific literature. Selected impact categories from the ReCiPe Midpoint $\mathrm{H}$ method [36] were used to compare the environmental performance of ethanol in the assessed routes, including the global warming potential (GWP), which is measured in $\mathrm{g}-\mathrm{CO}_{2}-\mathrm{eq} \mathrm{kg}^{-1} \mathrm{EtOH}$; human toxicity potential (HTP), which is measured in g-1,4-DB-eq $\mathrm{kg}^{-1}$ EtOH (where 1,4-DB corresponds to 1,4-dichlorobenzene); terrestrial acidification potential (TAP), which is measured in $\mathrm{g}-\mathrm{SO}_{2}-\mathrm{eq} \mathrm{kg}^{-1} \mathrm{EtOH}$; freshwater eutrophication (FWE), which is measured in g-P-eq $\mathrm{kg}^{-1}$ $\mathrm{EtOH}$; agricultural land occupation (ALO), which is measured in $\mathrm{m}^{2} \mathrm{a} \mathrm{kg}$ EtOH; and fossil depletion potential (FDP), which is measured in g-oil-eq $\mathrm{kg}^{-1}$ EtOH.

The life cycle inventories used in this assessment were obtained from the results of agricultural (CanaSoft software, [37]) and industrial (technical assessment, section 2,2) simulations using the VSB framework. Because multiple products were obtained in each scenario, i.e., ethanol, sugar, electricity and $\mathrm{H}_{2}$, depending on the biodigestion scheme, the environmental impacts were allocated to each product as predicted by the LCA methodology. In this study, the allocation procedure based on economic relationships was employed as described in the ISO 14040 and 14044 documents [31,32].

\section{Results and discussion}

\subsection{Bioenergy generation from biogas}

Data on the bioenergy generated from biogas are depicted in Fig. 2a-b and include both the electric and thermal fractions. An overall analysis indicates that the application of biohythane as fuel (CE-3) could lead to energy gains compared with the use of biogas$\mathrm{CH}_{4}$, regardless of the prime mover and the AD process scheme, i.e., single- or two-phase systems. Such a pattern results from a more efficient combustion of $\mathrm{CH}_{4}$ based on the previously highlighted advantages, which increased the conversion of biogas into electric energy, regardless of the prime mover (Fig. 2c). Particularly for biogas streams, the addition of $\mathrm{H}_{2}$ minimizes dilution effects from $\mathrm{CO}_{2}$, which allows for the use of lean-burn (excess air supply) conditions in engines. In such cases, the provision of higher oxygen levels also leads to a more efficient combustion, which favors the role of $\mathrm{H}_{2}$ as an enhancer of energy generation [38].

Biogas- $\mathrm{H}_{2}$ purification followed by $\mathrm{H}_{2}$ injection into the methanogenic reactors (CE-4) leads to similar results compared with CE3 (Fig. 2a-b). In this case, energy gains are related to an increase in the lower heating value (LHV) of biogas- $\mathrm{CH}_{4}$, i.e., $21.96 \mathrm{MJ} \mathrm{m}^{-3}$ (CE4) vs. $20.92 \mathrm{MJ} \mathrm{m}^{-3}$ (CE-1 and $\mathrm{CE}-2$ ), based on a higher $\mathrm{CH}_{4}$ content $(\sim 75 \%)$ in biogas. Such scenarios simulated the enhancement of hydrogenotrophic activity in the methanogenic phase; therefore, the reduction in $\mathrm{CO}_{2}$ content in the biogas- $\mathrm{CH}_{4}$ also improved its combustion properties. Compared with the use of biohythane (CE3 ), the main drawback from scenario $\mathrm{CE}-4$ is related to the need to remove $\mathrm{CO}_{2}$ from biogas $-\mathrm{H}_{2}$ prior to its injection into the methanogenic phase to prevent an imbalance of inorganic carbon levels in the reactor as well as energy losses because of the accumulation of $\mathrm{CO}_{2}$ in biogas $-\mathrm{CH}_{4}$. Although biohythane formation via biogas- $\mathrm{H}_{2}$ and biogas- $\mathrm{CH}_{4}$ blending decreased the LHV of biogas- $\mathrm{CH}_{4}$, i.e., $16.07 \mathrm{MJ} \mathrm{m}^{-3}$ (CE-3) vs. $20.92 \mathrm{MJ} \mathrm{m}^{-3}$ (CE-1 and $\left.\mathrm{CE}-2\right)$, the improved combustion properties of $\mathrm{H}_{2}$ most likely offset such dilution effects in scenario CE-3.

An alternative method of utilizing biogas- $\mathrm{H}_{2}$ could be the direct generation of electricity in fuel cells after the removal of $\mathrm{CO}_{2}$. In this case, an increment of approximately $382 \mathrm{~kW}$ would be observed in the amount of electricity generated in the harvesting period in scenarios $\mathrm{CE}-1 / \mathrm{CE}-2$, where the $\mathrm{H}_{2}$ from the acidogenic phase was not recovered (CE-1) or used to directly recover bioenergy (CE-2). Estimates considered specifications from a Ballard ClearGen fuel cell with an electric conversion efficiency of $40 \%$. However, comparatively higher electric increments were simulated through both the application of biogas- $\mathrm{H}_{2}$ to biohythane production (CE-3; $502-545 \mathrm{~kW}$, respectively, for ICE and CC) and the in loco biogas$\mathrm{CH}_{4}$ upgrade via enhanced hydrogenotrophic methanogenesis (CE4; 467-479 kW, respectively, for ICE and CC), and these simulations also used scenarios CE-1/CE-2 as the baseline. In addition to the lower electricity generation, the investment costs with the fuel cells would be over $90-150 \%$ of the incremental investments required by the application of biohythane (CE-3) or upgraded biogas- $\mathrm{CH}_{4}$ (CE-4) into ICEs, GTBs, or CCs, which features the use of conventional prime movers as a more attractive approach for exploiting both biogas $-\mathrm{H}_{2}$ and biogas- $\mathrm{CH}_{4}$ streams.

Bioenergy generation in scenarios with single-phase AD processes (CE-5) reached values that were at least $20 \%$ lower compared with two-phase schemes (Fig. 2a-b), regardless of the strategy used to implement the biogas- $\mathrm{H}_{2}$ and the type of prime mover Despite the slightly lower influent COD compared with singlephase reactors, such results reflect the enhanced performance of methanogenic reactors preceded by acidogenic systems as observed in the higher organic matter conversion rates and methane yields (Table 1). Fig. 3a-b compare the electric energy production levels observed herein with data from similar studies (based on single-phase processes), also indicating higher levels for systems with phase separation. In addition to the advantages of pre-acidifying the wastewaters, the observed differences also resulted from specific assumptions considered in each analysis, such as the size of the ethanol plant and mainly the specific vinasse generation. The vinasse generation observed in this study $\left(8.6 \mathrm{~m}^{3}\right.$ per $\mathrm{m}^{3}$ of ethanol, Table 1 ) was considerably lower than the average values observed in ethanol plants $\left(12-14 \mathrm{~m}^{3}\right.$ per $\mathrm{m}^{3}$ of ethanol $[4,9,39])$. Nevertheless, the operation of AD-power plants during the inter-harvest could increase electric energy generation by $50 \%$ (Fig. 3b), which was based on values from the harvesting period as reference.

Considering a wider analysis, the electric energy obtained from vinasse $\mathrm{AD}(8.35-12.97 \mathrm{kWh}$ per ton of sugarcane $-\mathrm{TC})$ during the harvesting period (CE-1 to CE-4) could replace $40-60 \%$ of the biorefinery electricity consumption (21.1 kWh TC ${ }^{-1}$, [40]) 
depending on the prime mover. With reference to the thermoelectric production from bagasse burning in cogeneration systems (46.2 $\mathrm{kWh} \mathrm{TC}^{-1}$, [40]), over $50 \%$ of the electric energy exported to the grid $\left(25.1 \mathrm{kWh} \mathrm{TC}^{-1}\right.$, [40]) could be achieved in AD-power plants with CC. Regarding the heat recovery within the scenarios with ICE and GTB (8.17-9.94 $\mathrm{kWh} \mathrm{TC}^{-1}$ ), slightly more than $2-3 \%$ of the thermal energy consumed in distilleries (300 $\mathrm{kWh} \mathrm{TC}^{-1}$, [41]) could theoretically be replaced with biogas, which characterizes the maximization of electric energy production as a more attractive option for the sucro-energetic sector.

The electricity obtained from biogas in the simulated biorefinery could reach values in the range of 33.4-51.9 $\times 10^{3} \mathrm{MWh}$ (harvest) and 11.2-17.2 $\times 10^{3} \mathrm{MWh}$ (inter-harvest) depending on the type of prime mover. AD-power plants based on the application of biohythane to the CC could supply populations as high as 140 and 60 thousand inhabitants in the periods of harvest $\left(51.9 \times 10^{3} \mathrm{MWh}\right)$ and inter-harvest $\left(17.2 \times 10^{3} \mathrm{MWh}\right)$, respectively, considering a monthly per capita energy consumption equivalent to $54.3 \mathrm{kWh}$ inhab $^{-1}$ (monthly residential energy consumption of $163 \mathrm{kWh}$ based on an average of three inhabitants per residence [42]). The total electric power achievable from vinasse AD for the 2014/2015 sugarcane harvest season considering the total amount of vinasse produced in this period in Brazil could vary within the range of 841-1319 MW based on a total ethanol production of 28.66 billion liters for the period [43] and the energy potential estimated for biogas within the scenarios with phase separation. In the context of Brazilian hydroelectric power generation, approximately $15-20 \%$ of the production from Tucuruí (8540 MW, [44]) and Itaipu (7000 MW, [44]) dams could be replaced by the energy from biogas, whereas more favorable patterns could be observed in relation to thermoelectric generation. Biogas energy obtained from vinasse could replace $35-55 \%$ of the total electricity produced by the 10 largest fuel oil-based Brazilian thermal plants in 2014 (2416 MW, [44]). For coal-based plants, such replacement values would vary

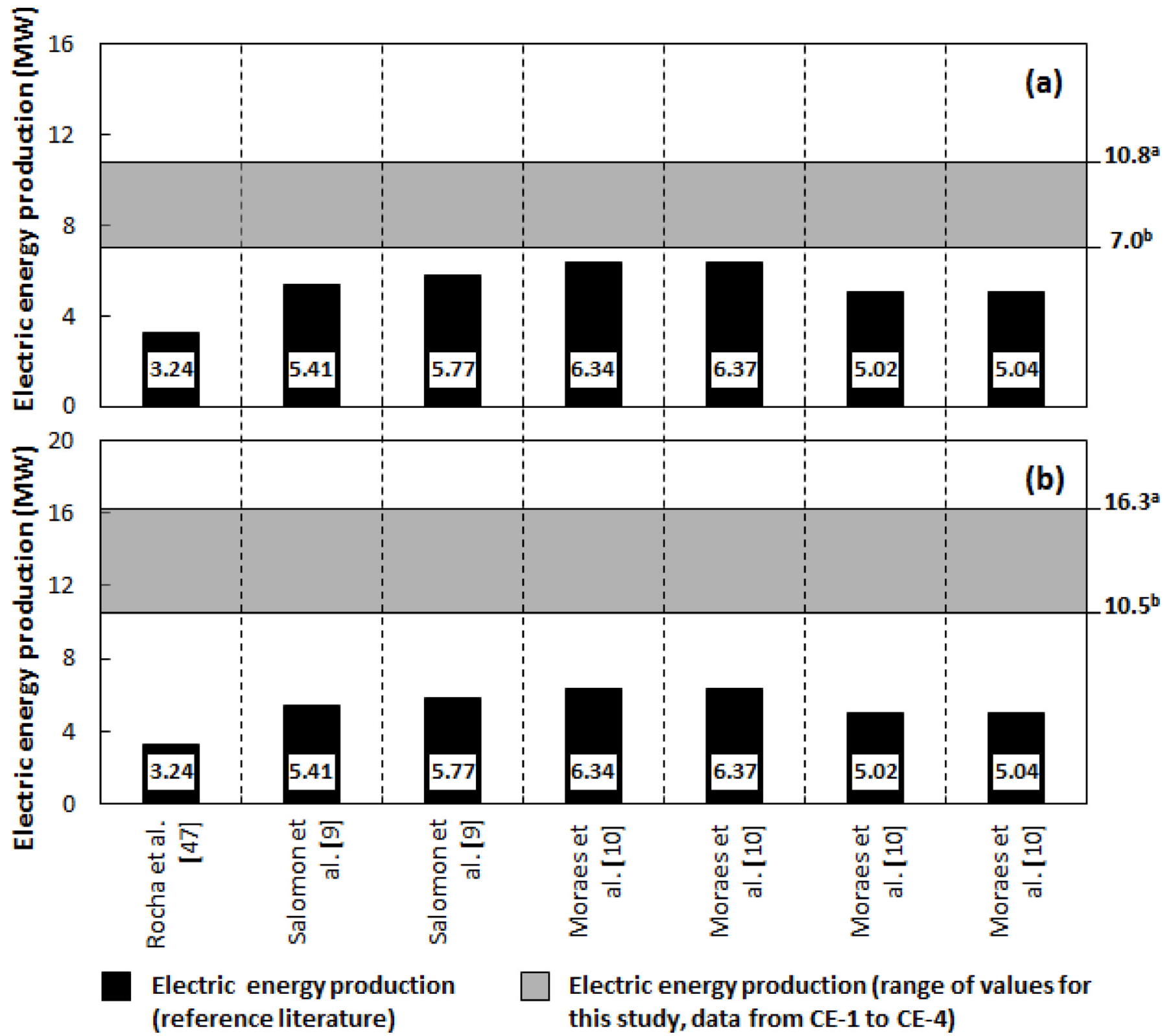

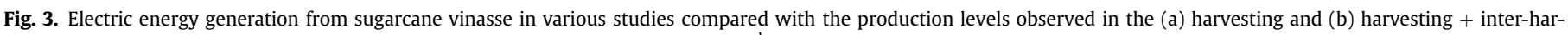
vesting periods. Note: Electric energy generation is based on scenarios ${ }^{\mathrm{a}} \mathrm{CE}-3-\mathrm{CC}$ and ${ }^{\mathrm{b}} \mathrm{CE}-1-\mathrm{ICE}$. Comparative data obtained from [9,10,47]. 
between 25 and $40 \%$ based on the accumulated electric production from the 10 largest Brazilian plants (3277 MW, [44]).

\subsection{Economic assessment}

Phase separation would lead to investment costs that are approximately $60 \%$ higher compared with single-phase $\mathrm{AD}$ schemes (10.16 vs. 6.24 million USD), and the main expenses are associated with the construction of reactors and equalization tanks. Fig. 4a details and compares the total investment costs for both AD and power plants in each scenario and shows that the values range from 22.12 to 26.91 million USD and from 16.58 to 17.79 million USD for two- and single-phase AD processes, respectively. Investments with the power plant accounted for more than $50 \%$ of the total installation costs (Fig. $4 \mathrm{~b}$ ) regardless of the prime mover, with higher values observed for scenarios with GTB as the sole prime mover because of the higher costs associated with heat recovery systems used for thermal energy generation. Biogas purification systems accounted for $7-8 \%$ of the total costs in the scenarios with $\mathrm{CO}_{2}$ removal from biogas- $\mathrm{H}_{2}$ (CE-2 and $\mathrm{CE}-4$; Fig. 4b), whereas the investments associated with $\mathrm{H}_{2} \mathrm{~S}$ removal from biogas- $\mathrm{CH}_{4}$ accounted for less than $1 \%$ of the total costs (CE-1 to $\mathrm{CE}-5$; Fig. 4b). The installation costs with AD-power plants corresponded to less than $10 \%$ of the total investments estimated for the sugarcane biorefinery in CB-0 (280.67 million USD), regardless of the prime mover.

Despite the higher investment costs (Fig. 4a), the economic parameters indicated that the implementation of $\mathrm{AD}$-power plants in the reference biorefinery would lead to feasible scenarios based on the positive NPV (USD 208.58-219.86 million) and higher IRR values relative to the MARR (12\%) (Fig. 5). For a given energetic scenario, changing the type of prime mover led to minimal alterations in the NPV, IRR, and payback period values, although the best conditions could always be associated with the use of a CC. Focusing on the cases with phase-separation AD plants, the most profitable option was achieved in scenario CE-1, which did not include the collection and use of biogas- $\mathrm{H}_{2}$. Despite the lower energy production in CE-1 (Fig. 2), specific characteristics of the plant favored such scenario in economic aspects, with emphasis on lower investments regarding the power plant (Fig. 4a).

The comparison between single- and two-phase AD systems depends directly on the type of alkalizing strategy used in the methanogenic phase because of the influence of the type and quantity of chemicals, i.e., $\mathrm{NaHCO}_{3}$ or $\mathrm{NaOH}$, over the operational expenditure (OPEX) in the assessed scenarios. For the strategy "NaHCO 3 -total", the NPV and IRR values would be 30\% and 9\% higher in the scenarios with phase separation, respectively (CE-1 to CE-4; Fig. 5). Slightly lower payback periods (6.6-6.8 vs. 7.6-7.7 years), which represent the time required to recover investment costs, also confirm that the best economic performance occurs with two-phase AD systems compared with single-phase processes. Despite the lower investment (24-27\%; Fig. 4) and lower operating costs compared with scenarios CE- 1 to CE-4, the higher costs of the chemicals $\left(\mathrm{NaHCO}_{3}\right)$ in scenarios with single-phase AD (CE-5) (28.53 vs. 15.05-16.70 million USD) would lead to a lower profitability, which is reflected in the higher production costs for ethanol
Investment (USD million)

0

10

20
Investment distribution (\%)

$300 \% \quad 25 \% \quad 50 \% \quad 75 \%$

$100 \%$

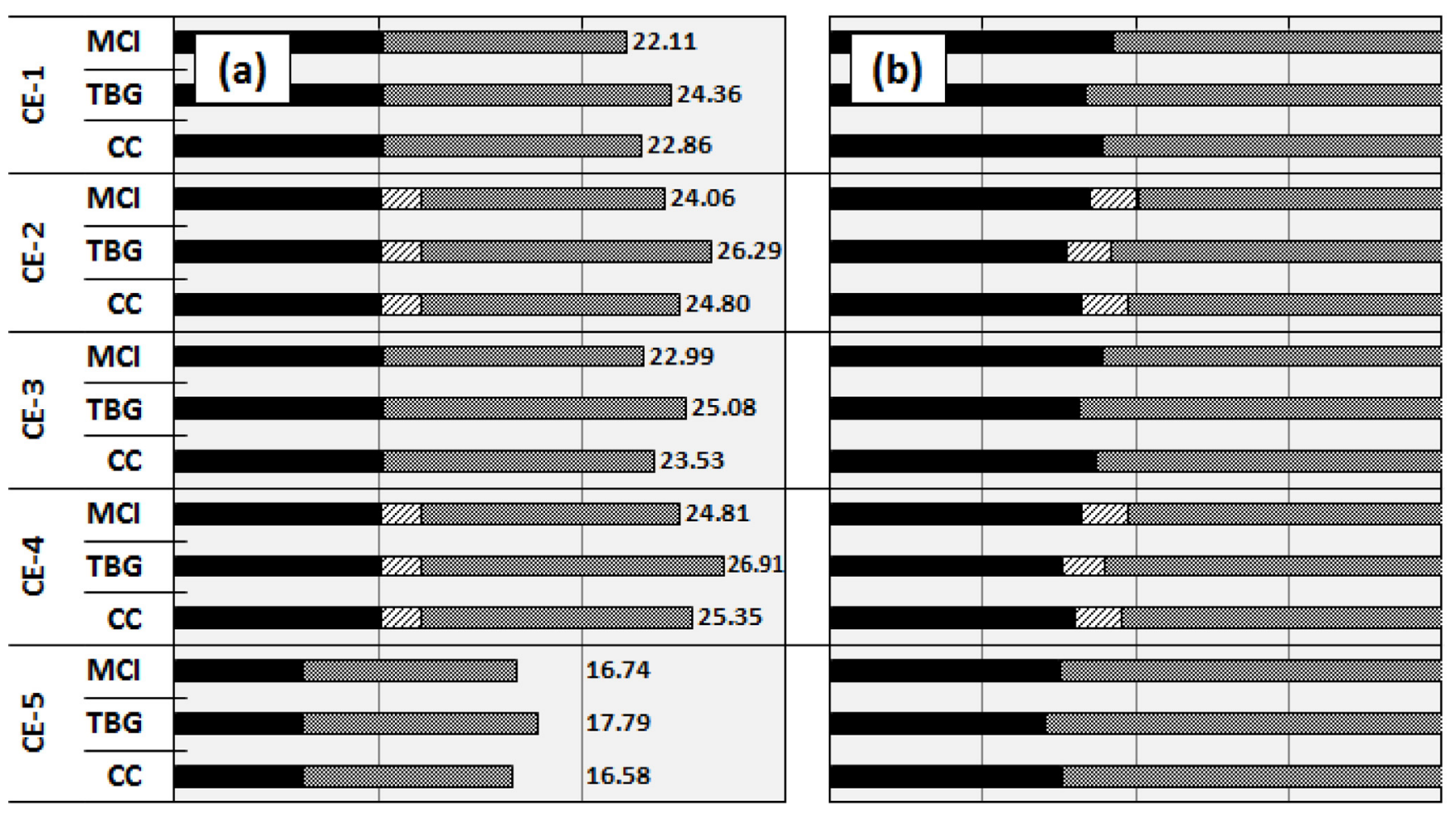

AD plant

\section{$\mathrm{CO}_{2}$ removal} (biogas- $\mathrm{H}_{2}$ )
$\mathrm{H}_{2} \mathrm{~S}$ removal
(biogas- $\mathrm{CH}_{4}$ )
Power plant

Fig. 4. (a) Total investment costs with AD-power plants and (b) the relative distribution of investment costs according to the plant components. 
(USD 0.28 per liter) and electric energy (USD 27.9 per MWh) observed in CE-5. The production costs for both ethanol and electric energy varied within the ranges of USD $0.25-0.26 \mathrm{~L}^{-1}$ and USD 25.6-26.0 $\mathrm{MWh}^{-1}$, respectively, in scenarios CE-1 to CE-4. Nevertheless, such an alkalizing strategy may not be feasible in largescale AD plants because the annual revenues from the electric energy produced via biogas would be less than $20 \%$ of the costs associated with the chemicals used in plants with phase separation (2.60 vs. 16.70 million USD, CE-3-CC).

Distinct patterns were observed with the alternative alkalizing strategies proposed herein. The application of $\mathrm{NaHCO}_{3}$ during only the startup period of the methanogenic phase considerably increased the NPV (259.95-271.23 million USD) and IRR (21.9-22.4\%) and reduced the payback period (5.8-6.0 years) in all scenarios, regardless of phase separation. For this alkalizing strategy, single-phase AD would be less economically attractive only when compared with scenarios CE-1 and CE-2. By replacing $\mathrm{NaHCO}_{3}$ with $\mathrm{NaOH}$ (NaOH-total), phase separation would not produce positive economic effects compared with single-phase processes, regardless of how the biogas- $\mathrm{H}_{2}$ is used, despite the similar economic performance (NPV $=270.19-281.47$ million USD, IRR $=22.2-22.7 \%$, payback $=5.6-5.8$ years for $C E-1$ to $C E-4$; $\mathrm{NPV}=282.71-285.32 \quad$ million $\quad$ USD, $\quad$ IRR $=22.9-23.0 \%$, payback $=5.5$ years for CE-5; Fig. $5 \mathrm{a}-\mathrm{f}$ ). The lower operating costs
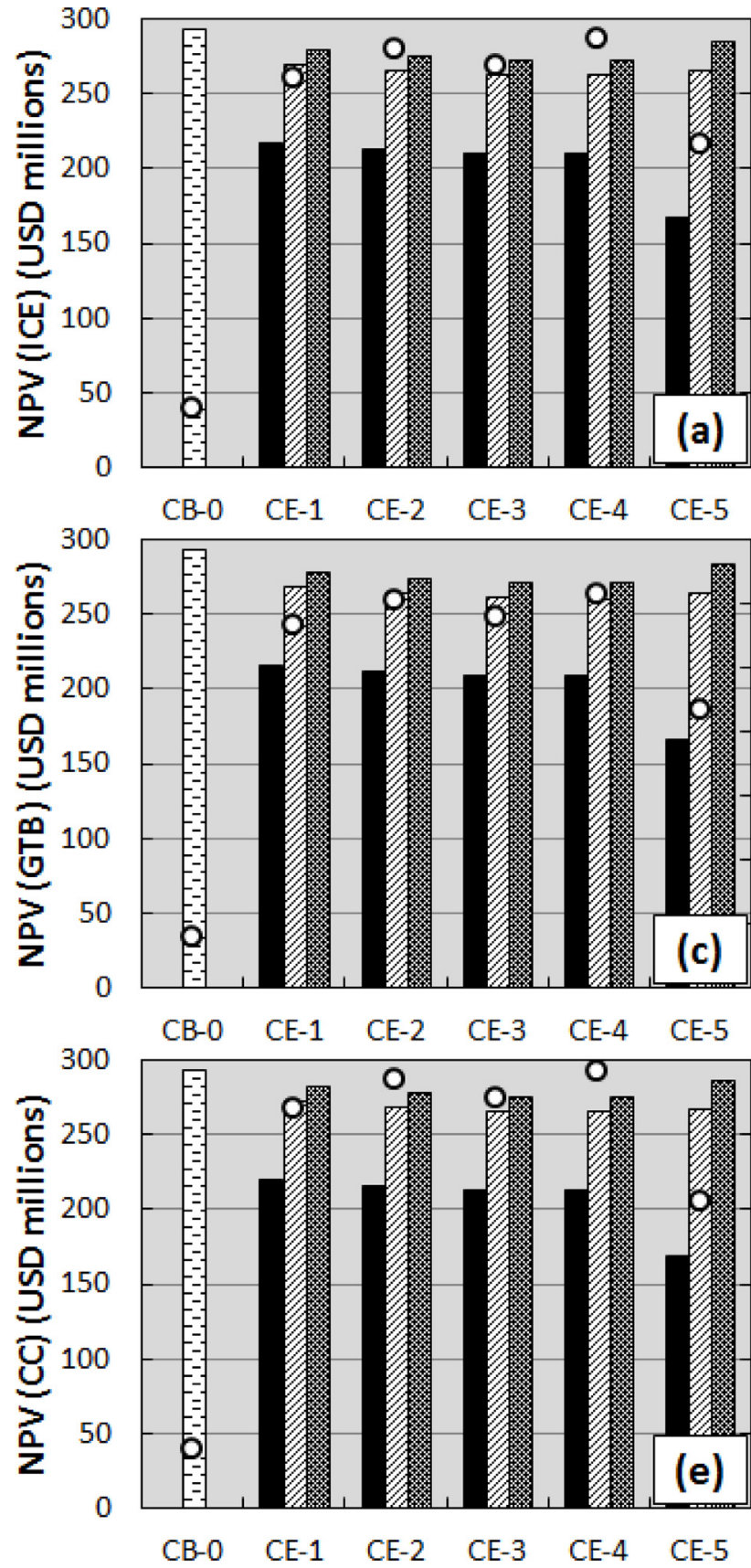

F-- Base scenario

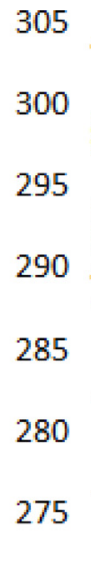

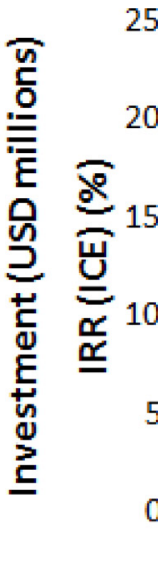

310

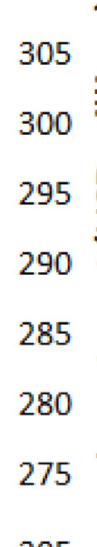

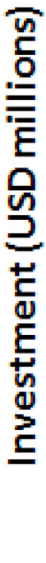

305

300

295

295

290

285

280

275

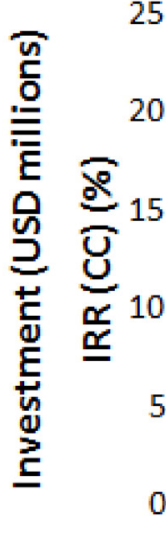

20

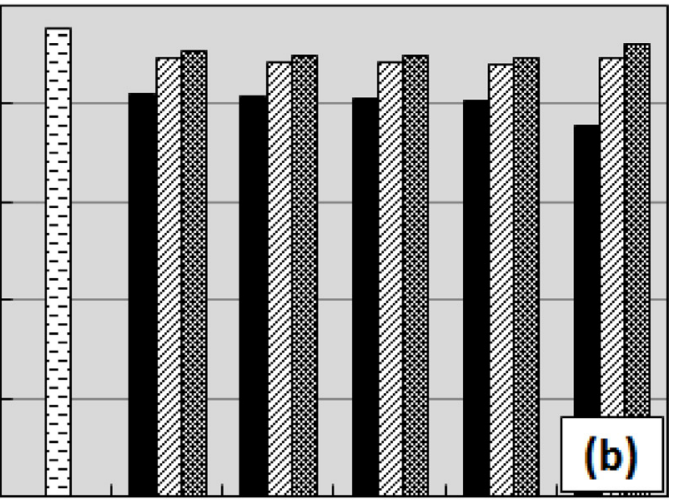

CB-0 $\quad$ CE-1 CE-2 CE-3 CE-4 CE-5

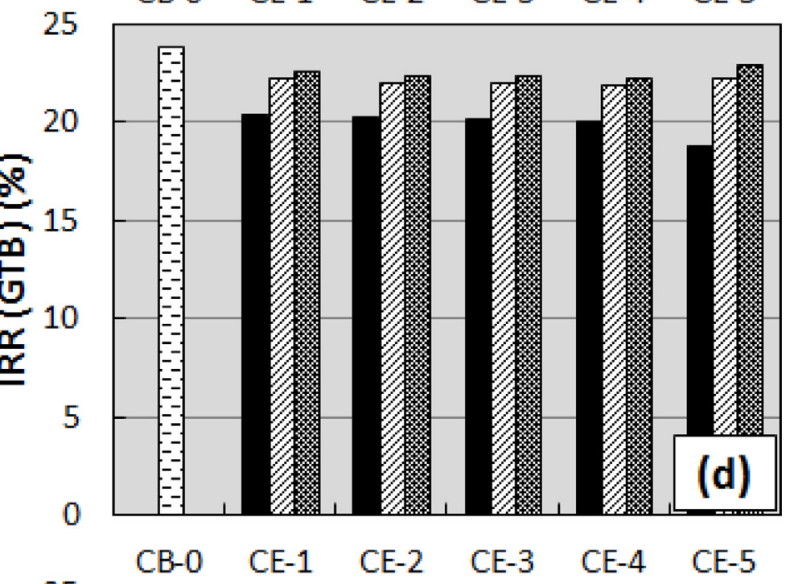

25
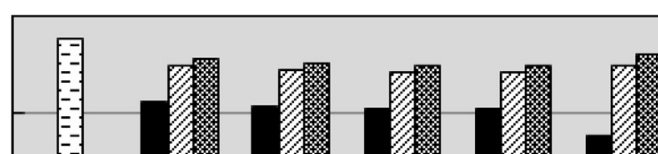

5

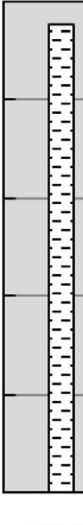

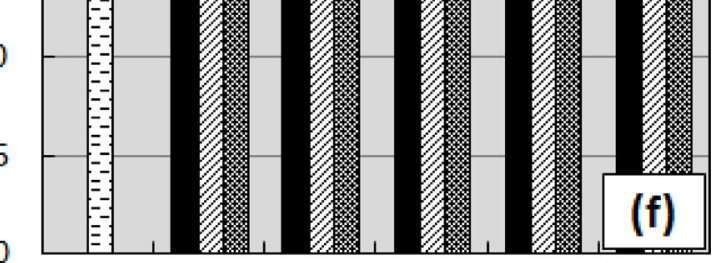

CB-0 CE-1 CE-2 CE-3 CE-4 CE-5

$\mathrm{NaHCO}_{3}$-startup $\mathrm{NaOH}$-total

Investment

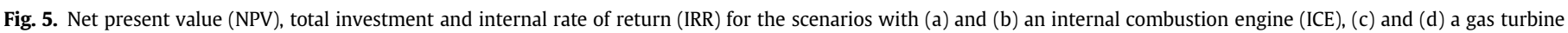
(GTB), and (e) and (f) a combined cycle (CC). 
with AD plants in scenario CE-5 explain the pattern in which the lower revenues from electric energy sales are offset.

Finally, although the base scenario (CB-0) indicated better economic results compared with the layouts implementing $A D$ $(\mathrm{NPV}=293.40$ million USD and $\mathrm{IRR}=23.9 \%$; Fig. 5, and payback $=5.2$ years), such a configuration may not be considered an adequate reference for comparison purposes. The reference scenario includes the direct land disposal of vinasse in natura, which may trigger a large variety of negative environmental effects
[4] and prevent bioenergy recovery through AD. In addition, the NPV and IRR values obtained for scenarios that implemented AD systems may be as high as the values observed for CB-0 depending on the alkalizing strategy, even when phase separation is considered, thereby coupling the positive technical and economic aspects of such systems. Further improvements in the economic performance of the AD-based scenarios could be achieved by including the production of an organomineral fertilizer from concentrated biodigested vinasse [45] because of the potential reductions in


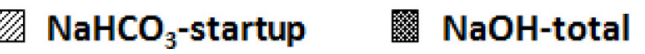

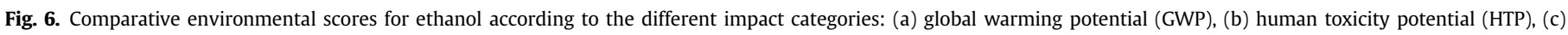
terrestrial acidification potential (TAP), (d) freshwater eutrophication (FWE), (e) agricultural land occupation (ALO), and (f) fossil depletion potential (FDP). 
fertilization costs for sugarcane production. The high liquid fraction of raw vinasse economically hinders its transportation for long distances, which limits its land disposal to a few kilometers from the biorefinery. In turn, the production of an organomineral fertilizer, which could include the concentration of the biodigested vinasse coupled to nitrogen supplementation [45], as well as the blending with other biorefinery byproducts (e.g. sugarcane trash and boiler ashes), would enable achieving higher distances, directly reducing inputs with mineral fertilization.

\subsection{Environmental performance assessment}

The LCA only considered scenarios based on the use of a CC for bioenergy generation because larger electric energy production levels could be coupled to minimal changes in the economic performance compared with use of the other prime movers as previously discussed (sections 3.1 and 3.2). The comparative environmental impacts of ethanol production for the selected impact categories in all scenarios are presented in Fig. 6, also considering different alkalizing strategies. The impacts for a given category are scored in each scenario and compared with each other, with the worst environmental performance associated with a value of $100 \%$. An overall analysis of the relative environmental impacts indicates similar performance for the categories GWP (Fig. 6a), TAP (Fig. 6c), and ALO (Fig. 6e), regardless of whether vinasse biodigestion and phase separation were implemented. Discrepancies related to the alkalizing strategy were also minimal in such cases. A similar pattern was also observed for the categories HTP (Fig. 6b), FWE (Fig. 6d), and FDP (Fig. 6f) when considering the alkalizing strategies $\mathrm{NaHCO}_{3}$-startup and $\mathrm{NaOH}$-total, whereas the worst environmental performance was clearly related to the strategy $\mathrm{NaHCO}_{3}$-total, primarily for single-phase AD schemes. Such results are similar to the trends observed for the economic assessment because the main drawbacks were associated with the high inputs of $\mathrm{NaHCO}_{3}$. The use of $\mathrm{NaOH}$ to adjust the $\mathrm{pH}$ of the raw vinasse prior to the acidogenic phase increased the environmental impacts of scenarios CE-2 to CE-4 only slightly compared with that of CE-1 based on the relative scores for the categories HTP (Fig. 6b), FWE (Fig. 6d), and FDP (Fig. 6f).

The environmental impact of ethanol production classified according to the categories GWP, HTP, FWE, and FDP is presented in Fig. 7 to highlight the effects of applying high dosages of $\mathrm{NaHCO}_{3}$. The drawbacks resulting from $\mathrm{NaHCO}_{3}$ production (Solvay process) are primarily based on the use of fossil fuels for thermal energy production, and they considerably increased the scores for GWP (Fig. 7a) and FDP (Fig. 7d). The high scores related to the biodigestion inputs in the category HTP (Fig. 7b) were also related to the consumption of fossil fuel for $\mathrm{NaHCO}_{3}$ production because the burning process increases the emissions of toxic compounds. The use of ammonia in the Solvay process also impacts the category HTP, although it generates lower scores compared with the emissions from fossil fuel burning. However, the emissions from nitrogen compounds, primarily from the use of ammonia, are the main factors that contributed to the high scores associated with $\mathrm{NaHCO}_{3}$ in the category FWE (Fig. 7c), although bicarbonate itself may stimulate the proliferation of aquatic macrophytes [46]. Junqueira et al. [45] also associated certain environmental drawbacks with the use of $\mathrm{NaHCO}_{3}$ in the biodigestion plants of sugarcane-based biorefineries treating vinasse; however, the impacts were a result of the indirect use of $\mathrm{NaOH}$ in the AD system because of its reaction with $\mathrm{CO}_{2}$ for the in loco production of $\mathrm{NaHCO}_{3}$.

Despite the drawbacks, particularly those associated with the use of $\mathrm{NaHCO}_{3}$ in the $\mathrm{AD}$ plant, the environmental performance of ethanol production was severely impacted in the HTP and FWE categories only when the $\mathrm{NaHCO}_{3}$-total strategy was implemented (Fig. 7). An overall analysis indicated that the impact from
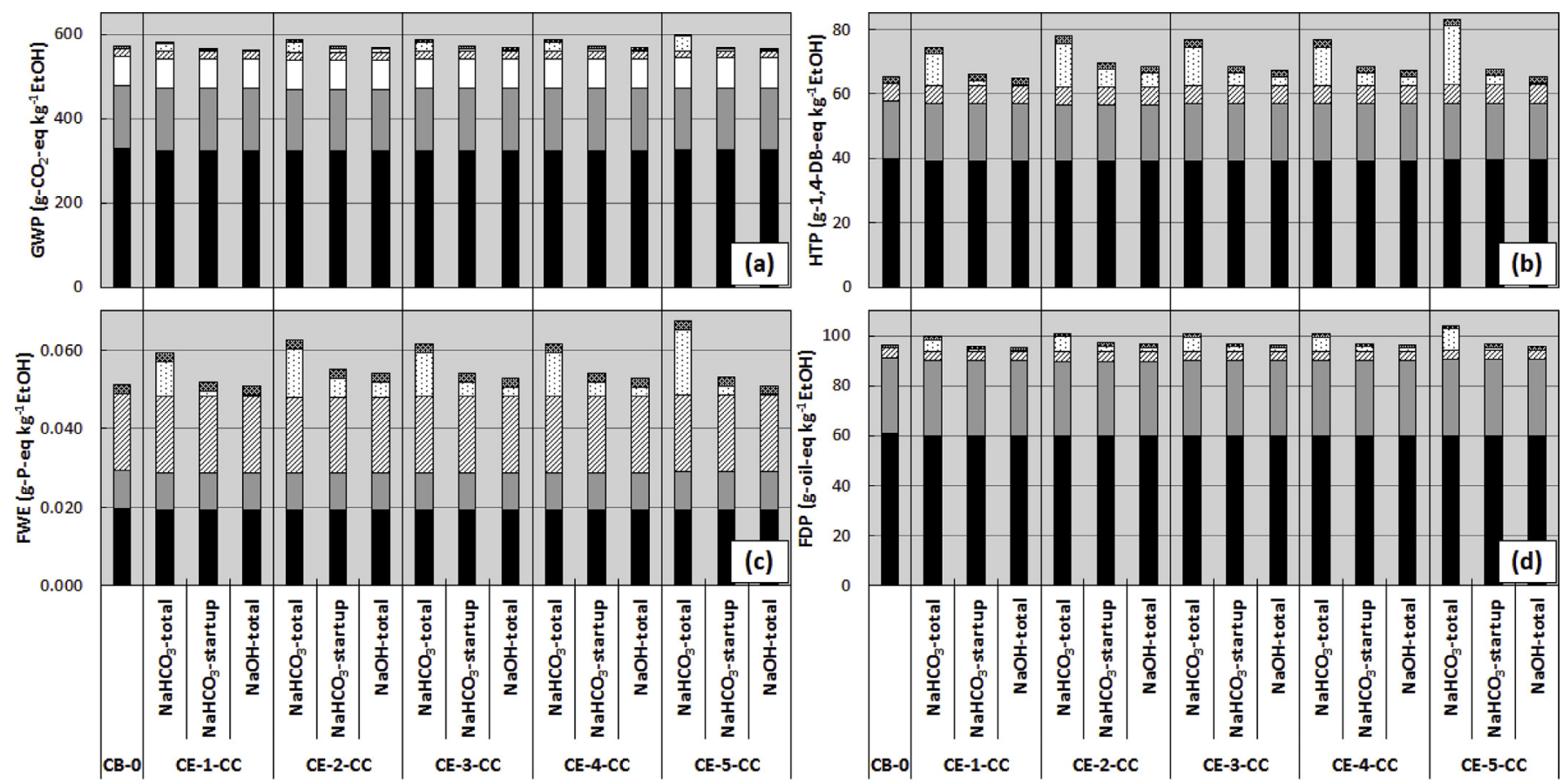

Sugarcane and straw

Energy cane

$\square$ Local emissions

Inputs - sugar and ethanol
Inputs - biodigestion

Equipment

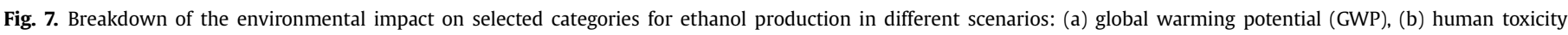
potential (HTP), (c) freshwater eutrophication (FWE), and (d) fossil depletion potential (FDP). 
implementing AD systems in biorefineries was considerably lower compared with the impact observed in the agricultural phase (Fig. 7). Furthermore, optimizing the alkalizing strategy (which is represented by the use of low dosages of $\mathrm{NaOH}$ in this study) slightly minimized the environmental impact from ethanol production. Such results indicate the possibility of associating energetic and environmental (to a less extent) gains with the maintenance of a comparable economic performance as the base scenario, i.e., without biodigestion, even when considering phase separation for the AD scheme.

\section{Conclusions}

The following conclusions can be drawn from this study:

- Biodigestion of vinasse with phase separation greatly enhances electric energy generation (20-30\% compared to single-phase schemes) without impairing the profitability of the sugarcane biorefinery, depending on the alkalinization strategy;

- Optimizing the alkalinization of methanogenic systems characterizes a determining factor to improve both the economic and environmental performance of $\mathrm{AD}$ plants by reducing operating costs and the risks associated to human toxicity and fresh water eutrophication;

- Enhanced electric energy generation may represent a more attractive option for distilleries compared with thermal energy because over $50 \%$ of the electric energy exported to the grid could be achieved in AD-power plants with a combined cycle; and,

- Implementing full-scale AD plants to treat sugarcane vinasse should be facilitated by using mechanisms that stimulate more efficient systems with regard to electric energy production and polluting load reductions, such as subsides to reduce investment costs and increase revenues via bioenergy.

\section{Acknowledgments}

The authors are grateful to the São Paulo Research Foundation (FAPESP), grant numbers 2009/15984-0 and 2012/15606-9, for supporting the development of this study.

\section{References}

[1] H.M. Poggi-Varaldo, K.M. Munoz-Paez, C. Escamilla-Alvarado, P.N. RobledoNarváez, M.T. Ponce-Noyola, G. Calva-Calva, E. Ríos-Leal, J. Galíndez-Mayer, C. Estrada-Vázquez, A. Ortega-Clemente, N.F. Rinderknecht-Seijas, Biohydrogen, biomethane and bioelectricity as crucial components of biorefinery of organic wastes: a review, Waste Manag. Res. 32 (2014) 353-365.

[2] M.O.S. Dias, T.L. Junqueira, O. Cavalett, L.G. Pavanello, M.P. Cunha, C.D.F. Jesus, R. Maciel Filho, A. Bonomi, Biorefineries for the production of first and second generation ethanol and electricity from sugarcane, Appl. Energy 109 (2013) $72-78$.

[3] E. España-Gamboa, J. Mijangos-Cortes, L. Barahona-Perez, J. Dominguez-Maldonado, G. Hernández-Zarate, L. Alzate-Gaviria, Vinasses: characterization and treatments, Waste Manag. Res. 29 (2011) 1235-1250.

[4] L.T. Fuess, M.L. Garcia, Implications of stillage land disposal: a critical review on the impacts of fertigation, J. Environ. Manag. 145 (2014) 210-229.

[5] Z.P. Jiang, Y.R. Li, G.P. Wei, Q. Liao, T.M. Su, Y.C. Meng, H.Y. Zhang, C.Y. Lu, Effect of long-term vinasse application on physico-chemical properties of sugarcane field soils, Sugar Tech. 14 (2012) 412-417.

[6] P. Sivaloganathan, B. Murugaiyan, S. Appavou, L. Dharmaraj, Effect of dilution of treated distillery effluent (TDE) on soil properties and yield of sugarcane, AJPS 4 (2013) 1811-1814.

[7] B.G. Oliveira, J.L.N. Carvalho, C.E.P. Cerri, C.C. Cerri, B.J. Feigl, Soil greenhouse gas fluxes from vinasse application in Brazilian sugarcane areas, Geoderma 200-201 (2013) 77-84.

[8] M.E. Souza, G. Fuzaro, A.R. Polegato, Thermophilic anaerobic digestion of vinasse in pilot plant UASB reactor, Water Sci. Technol. 25 (7) (1992) $213-222$.

[9] K.R. Salomon, E.E.S. Lora, M.H. Rocha, O.A. del Olmo, Cost calculations for biogas from vinasse biodigestion and its energy utilization, Sugar Ind. 136 (4)
(2011) 217-223.

[10] B.S. Moraes, T.L. Junqueira, L.G. Pavanello, O. Cavalett, P.E. Mantelatto, A. Bonomi, M. Zaiat, Anaerobic digestion of vinasse from sugarcane biorefineries in Brazil from energy, environmental, and economic perspectives: profit or expense? Appl. Energy 113 (2014) 825-835.

[11] L.T. Fuess, M.L. Garcia, Anaerobic digestion of stillage to produce bioenergy in the sugarcane-to-ethanol industry, Environ. Technol. 35 (2014) 333-339.

[12] L.T. Fuess, M.L. Garcia, Bioenergy from stillage anaerobic digestion to enhance the energy balance ratio of ethanol production, J. Environ. Manag. 162 (2015) $102-114$.

[13] S.C. Santos, P.R.F. Rosa, I.K. Sakamoto, M.B.A. Varesche, E.L. Silva, Hydrogen production from diluted and raw sugarcane vinasse under thermophilic anaerobic conditions, Int. J. Hydrogen Energy 39 (2014) 9599-9610.

[14] A.D.N. Ferraz Jr., C. Etchebehere, M. Zaiat, High organic loading rate on thermophilic hydrogen production and metagenomic study at an anaerobic packed-bed reactor treating a residual liquid stream of a Brazilian biorefinery, Bioresour. Technol. 186 (2015) 81-88.

[15] L.T. Fuess, L.S.M. Kiyuna, M.L. Garcia, M. Zaiat, Operational strategies for longterm biohydrogen production from sugarcane stillage in continuous acidogenic packed-bed reactor, Int. J. Hydrogen Energy 41 (2016) 8132-8145.

[16] S.J. Sarma, V. Pachapur, S. Kaur Brar, Y. Le Bihan, G. Buelna, Hydrogen biorefinery: potential utilization of the liquid waste from fermentative hydrogen production, Renew. Sustain. Energy Rev. 50 (2015) 942-951.

[17] A.D.N. Ferraz Jr., M.H. Koyama, M.M. Araújo Jr., M. Zaiat, Thermophilic anaerobic digestion of raw sugarcane vinasse, Renew. Energy 89 (2016) $245-252$.

[18] L.T. Fuess, M.M. Araújo Jr., M.L. Garcia, M. Zaiat, Designing full-scale biodigestion plants for the treatment of vinasse in sugarcane biorefineries: how phase separation and alkalinization impact biogas and electricity production costs? Chem. Eng. Res. Des. 119 (2017) 209-220.

[19] C. Jeong, T. Kim, K. Lee, S. Song, K.M. Chun, Generating efficiency and emissions of a spark-ignition gas engine generator fuelled with biogas-hydrogen blends, Int. J. Hydrogen Energy 34 (2009) 9620-9627.

[20] EPA, Catalog of CHP Technologies, U.S. Environmental Protection Agency, Combined Heat and Power Partnership, 2015. https://www.epa.gov/sites/ production/files/2015-07/documents/catalog_of_chp_technologies.pdf. (Accessed 11 January 2016).

[21] Z. Liu, C. Zhang, Y. Lu, X. Wu, L. Wang, L. Wang, B. Han, X.H. Xing, States and challenges for high-value biohythane production from waste biomass by dark fermentation technology, Bioresour. Technol. 135 (2013) 292-303.

[22] C. Cavinato, D. Bolzonella, F. Fatone, F. Cecchi, P. Pavan, Optimization of twophase thermophilic anaerobic digestion of biowaste for hydrogen and methane production through reject water recirculation, Bioresour. Technol 102 (2011) 8605-8611.

[23] C. Cavinato, A. Giuliano, D. Bolzonella, P. Pavan, F. Cecchi, Bio-hythane production from food waste by dark fermentation coupled with anaerobic digestion process: a long-term pilot scale experience, Int. J. Hydrogen Energy 37 (2012) 11549-11555.

[24] G. Luo, I. Angelidaki, Integrated biogas upgrading and hydrogen utilization in an anaerobic reactor containing enriched hydrogenotrophic methanogenic culture, Biotechnol. Bioeng. 109 (11) (2012) 2729-2736.

[25] G. Luo, S. Johansson, K. Boe, L. Xie, Q. Zhou, I. Angelidaki, Simultaneous hydrogen utilization and in situ biogas upgrading in an anaerobic reactor, Biotechnol. Bioeng. 109 (4) (2012) 1088-1094.

[26] L.T. Fuess, L.S.M. Kiyuna, A.D.N. Ferraz Jr. G.F. Persinoti, F.M. Squina, M.L. Garcia, M. Zaiat, Thermophilic two-phase anaerobic digestion using an innovative fixed-bed reactor for enhanced organic matter removal and bioenergy recovery from sugarcane vinasse, Appl. Energy 189 (2017) 480-491.

[27] A. Bonomi, O. Cavalett, M.P. Cunha, M.A.P. Lima, The virtual sugarcane biorefinery concept, in: A. Bonomi, O. Cavalett, M.P. Cunha, M.A.P. Lima (Eds.), Virtual Biorefinery: an Optimization Strategy for Renewable Carbon Valorization, Springer, London, 2016, pp. 5-12.

[28] T.L. Junqueira, M.F. Chagas, V.L.R. Gouveia, M.C.A.F. Rezende, M.D.B. Watanabe, C.D. F, O. Cavalett, A.Y. Milanez, A. Bonomi, Techno-economic analysis and climate change impacts of sugarcane biorefineries considering different time horizons, Biotechnol. Biofuels 10 (2017) 50.

[29] O. Cavalett, T.L. Junqueira, M.O.S. Dias, C.D.F. Jesus, P.E. Mantelatto, M.P. Cunha, H.C.J. Franco, T.F. Cardoso, R. Maciel Filho, C.E.V. Rossell, A. Bonomi, Environmental and economic assessment of sugarcane first generation biorefineries in Brazil, Clean Technol. Environ. 14 (3) (2012) 399-410.

[30] R. Muñoz, L. Meier, I. Diaz, D. Jeison, A critical review on the state-of-the-art of physical/chemical and biological technologies for an integral biogas upgrading, Rev. Environ. Sci. Biotechnol. 14 (4) (2015) 727-759.

[31] ISO, ISO Norm 14040:2006, Life Cycle Assessment: Principles and Framework. Environmental Management, International Organisation for Standardisation, Geneva, 2006.

[32] ISO, ISO Norm 14044:2006, Life Cycle Assessment. Requirements and Guidelines. Environmental Management, International Organisation for Standardisation, Geneva, 2006.

[33] M.D.B. Watanabe, L.G. Pereira, M.F. Chagas, M.P. Cunha, C.D.F. Jesus, A. Souza, E.C. Rivera, R. Maciel Filho, O. Cavalett, A. Bonomi, Sustainability assessment methodologies, in: A. Bonomi, O. Cavalett, M.P. Cunha, M.A.P. Lima (Eds.) Virtual Biorefinery: an Optimization Strategy for Renewable Carbon Valorization, Springer, London, 2016, pp. 155-188.

[34] PRé Consultants, SimaPro Life Cycle Assessment Software. http://www.pre- 
sustainability.com/simapro, 04 April 2016

[35] Ecoinvent, Ecoinvent Reports No.1-25, Swiss Centre for Life Cycle Inventories, Dübendorf, 2007.

[36] M.J. Goedkoop, R. Heijungs, M. Huijbregts, A. De Schryver, J. Struijs, R. van Zelm, ReCiPe 2008 - a Life Cycle Impact Assessment Method Which Comprises Harmonised Category Indicators at the Midpoint and the Endpoint Level, first ed., 2009. Report I: Characterisation, http://www.leidenuniv.nl/ $\mathrm{cml} / \mathrm{ssp} /$ publications/recipe_characterisation.pdf. (Accessed 4 April 2016).

[37] O. Cavalett, M.F. Chagas, P.S.G. Magalhães, J.L.N. Carvalho, T.F. Cardoso, H.C.J. Franco, O.A. Braunbeck, A. Bonomi, The agricultural production model in: A. Bonomi, O. Cavalett, M.P. Cunha, M.A.P. Lima (Eds.), Virtual Biorefinery: an Optimization Strategy for Renewable Carbon Valorization, Springer, London, 2016, pp. 13-52.

[38] E. Porpatham, A. Ramesh, B. Nagalingam, Investigation on the effect of concentration of methane in biogas when used as a fuel for a spark ignition engine, Fuel 87 (2008) 1651-1659.

[39] M.O.S. Dias, R. Maciel Filho, P.E. Mantelatto, O. Cavalett, C.E.V. Rossell, A. Bonomi, M.R.L.V. Leal, Sugarcane processing for ethanol and sugar in Brazil Environ. Dev. 15 (2015) 35-51.

[40] CONAB, A geração termoelétrica com a queima do bagaço de cana-de-açúca no Brasil: análise do desempenho da safra 2009-2010, CONAB, Brasília, 2011. http://www.conab.gov.br/OlalaCMS/uploads/arquivos/11_05_05_15_45_40_ geracao_termo_baixa_res.pdf. (Accessed 26 May 2015) (in Portuguese).

[41] H.M. Lamonica, Produção de vapor e eletricidade - a evolução do setor sucroalcooleiro, in: II Workshop de Gestão de Energia e Resíduos na Agroindústria Sucroalcooleira, Pirassununga, SP, Brazil, 2007. http://www.usp.br
green/downloads/5\%20-\%20Helcio\%20M.\%20Lamonica.pdf. (Accessed February 2016) (in Portuguese).

[42] EPE, 2014 Statistical yearbook of electricity - 2013 baseline year, EPE, Rio de Janeiro, 2014. http://www.epe.gov.br/AnuarioEstatisticodeEnergiaEletrica/ Anu\%C3\%A1rio\%20Estat\%C3\%ADstico\%20de\%20Energia\%20El\%C3\%A9trica\% 202014.pdf. (Accessed 11 January 2016).

[43] CONAB, Monitoramento da safra brasileira: cana-de-açúcar (safra 2014/2015). Quarto levantamento, Abril/2015, CONAB, Brasília, 2015. http://www.conab. gov.br/OlalaCMS/uploads/arquivos/15_04_13_08_49_33_boletim_cana_ portugues_- 10_lev_-_15-16.pdf. (Accessed 8 February 2016) (in Portuguese).

[44] MME, Capacidade instalada de geração elétrica - Brasil e mundo, 2014. http:// www.mme.gov.br/documents/1138787/0/Capacidade+Instalada+de+EE+ 2014.pdf/cb1d150d-0b52-4f65-a86b-b368ee715463. (Accessed 21 March 2016) (in Portuguese)

[45] T.L. Junqueira, B. Moraes, V.L.R. Gouveia, M.F. Chagas, E.R. Morais, M.D.B. Watanabe, M. Zaiat, A. Bonomi, Use of VSB to plan research programs and public policies, in: A. Bonomi, O. Cavalett, M.P. Cunha, M.A.P. Lima (Eds.) Virtual Biorefinery: an Optimization Strategy for Renewable Carbon Valorization, Springer, London, 2016, pp. 257-282.

[46] A. Freitas, S.M. Thomaz, Inorganic carbon shortage may limit the development of submersed macrophytes in habitats of the Paraná River basin, Acta Limnol. Bras. (Online) 23 (1) (2011) 57-62.

[47] M.H. Rocha, E.E.S. Lora, OJ Venturini, J.C.P. Escobar, JJ.C.S. Santos, A.G. Moura, Use of the life cycle assessment (LCA) for comparison of the environmental performance of four alternatives for the treatment and disposal of bioethanol stillage, Int. Sugar J. 112 (2010) 611-622. 